\title{
Identification of fatty acid oxidation disorder patients with lowered acyl-CoA thioesterase activity in human skin fibroblasts
}

\author{
Mary Hunt \\ Technological University Dublin, mary.hunt@tudublin.ie \\ Jos Ruiter \\ University of Amsterdam \\ Petra Mooyer \\ University of Amsterdam
}

See next page for additional authors

Follow this and additional works at: https://arrow.tudublin.ie/scschbioart

Part of the Medical Biochemistry Commons, and the Molecular Biology Commons

\section{Recommended Citation \\ Hunt, M., Ruiter, P., Mooyer, C., Van Roermond, T., Ofman, R., Ljlst, L., Wanders, R.: Identification of fatty acid oxidation disorder patients with lowered acyl-CoA thioesterase activity in human skin fibroblasts. European Journal of Clinical Investigation, Vol. 35, (1) 2005, pp. 38-46. doi:10.1111/ j.1365-2362.2005.01447.x}

This Article is brought to you for free and open access by the School of Biological Sciences at ARROW@TU Dublin. It has been accepted for inclusion in Articles by an authorized administrator of ARROW@TU Dublin. For more information, please contact arrow.admin@tudublin.ie, aisling.coyne@tudublin.ie,gerard.connolly@tudublin.ie.






\section{Authors}

Mary Hunt, Jos Ruiter, Petra Mooyer, Carlo W T van Roermond, Rob Ofman, Lodewig ljlst, and Ronald J A Wanders 


\title{
Identification of fatty acid oxidation disorder patients with lowered acyl-CoA thioesterase activity in human skin fibroblasts.
}

\author{
Mary C. Hunt ${ }^{*}$, Jos Ruiter\#, Rob Ofman\#, Lodewijk IJlst\#, \\ Carlo W.T. van Roermond\#, Petra Mooyer\# and Ronald J. A. Wanders\#. \\ *Department of Laboratory Medicine, Division of Clinical Chemistry C1-74, \\ Karolinska University Hospital at Huddinge, SE 14186 Stockholm, Sweden, and \\ the \#Department of Clinical Chemistry, Academic Medical Centre, University of \\ Amsterdam, P.O. Box 22700, 1100 DE Amsterdam, The Netherlands.
}

\author{
Address for correspondence: \\ Dr. Mary C. Hunt \\ Department of Laboratory Medicine \\ Division of Clinical Chemistry C1-74 \\ Karolinska University Hospital at Huddinge Phone: +46-8-58581293 \\ SE-141 86 Stockholm \\ Sweden \\ Fax: $+46-8-58581260$ \\ email: mary.hunt@labmed.ki.se
}

Running title: Identification of patients with lowered acyl-CoA thioesterase activity

\section{Acknowledgements}

This study is supported by European Molecular Biology Organization (EMBO) Short Term Fellowship, Novartis Stiftelse för Medicinsk-Biologisk Forskning, Svenska Sällskapet för Medicinsk Forskning, Åke Wibergs stiftelse, HjärtLungfonden, Lars Hiertas Minne, Fredrik och Ingrid Thurings Stiftelse, Ruth och Richard Juhlins Stiftelse, Stiftelsen Professor Nanna Svartz fond and the National Network for Cardiovascular Research (Sweden).

Word count of total text (inc references) $-4,843$

Character count-28,761 


\section{Abstract}

Background: Acyl-CoA thioesterases are enzymes that hydrolyze acyl-CoAs to the free fatty acid and coenzyme A (CoASH). These enzymes have been identified in several cellular compartments and are thought to regulate intracellular levels of acyl-CoAs, free fatty acids and CoASH. However, to date no patients deficient in acyl-CoA thioesterases have been identified.

Design: Acyl-CoA thioesterase activity was measured in human skin fibroblasts. Western blot analysis was used to determine Type-II acyl-CoA thioesterase protein levels in patients.

Results: Activity was found in human fibroblasts with all saturated acyl-CoAs from C4:0- to C18:0-CoA, with highest activity detected with lauroyl-CoA and myristoyl-CoA (C12:0 and C14:0-CoA). An antibody that recognizes all isoforms of Type-II acyl-CoA thioesterases, precipitated the majority of acyl-CoA thioesterase activity in fibroblasts, showing that the major activity in fibroblasts is catalyzed by Type-II thioesterases. Measurement of acyl-CoA thioesterase activity from fibroblasts of 40 patients with putative fatty acid oxidation disorders resulted in the identification of 3 patients with lowered Type-II acylCoA thioesterase activity in fibroblasts. These patients also had lowered expression of Type-II acyl-CoA thioesterase protein in fibroblasts as judged by Western blot analysis. However, mutation analysis failed to identify any mutation in the coding sequences for the mitochondrial acyl-CoA thioesterase II (MTE-II) or the cytosolic acyl-CoA thioesterase II (CTE-II).

Conclusions: We have described 3 patients with lowered Type-II acyl-CoA thioesterase protein and activity in human skin fibroblasts, which is the first description of patients with a putative defect in acyl-CoA thioesterases. 
Key words: acyl-CoA thioesterase, acyl-CoA hydrolase, fatty acid oxidation disorders, [-oxidation, mitochondria 


\section{Introduction}

Acyl-CoA thioesterases (EC 3.1.2.2) are a group of enzymes that hydrolyze acylCoA esters to the free fatty acid and coenzyme A (CoASH). The activity has been localized to cellular compartments such as endoplasmic reticulum, cytosol, mitochondria, and peroxisomes. Several different families of acyl-CoA thioesterases have been identified and characterized in detail (for review see [1]). These enzymes are thought to be mainly involved in controlling levels of CoA esters, free fatty acids and coenzyme A (CoA) within different compartments in the cell. It has now become evident that both free fatty acids and the CoA-esters of fatty acids are important in regulating different cellular processes and cell signaling. Cellular processes involving acyl-CoAs are degradation of fatty acids via -oxidation, allosteric regulation of several enzymes [2], activation of pancreatic beta-cell $\mathrm{K}_{\mathrm{ATP}}$ channels [3], agonists / antagonists for nuclear receptors peroxisome proliferator-activated receptors (PPARs) [4-7] and Hepatic Nuclear Factor 4 alpha (HNF-4 $\square$ ) [8], together with numerous other cellular processes reviewed in [9].

Several evolutionary unrelated families of acyl-CoA thioesterases have now been identified and functionally linked to lipid metabolism. One family of acyl-CoA thioesterases identified in the 1980's was named Type-II acyl-CoA thioesterases. This enzyme activity was first identified in cytosol by Miyazawa et al [10] and two isoforms of these enzymes were later cloned from rat [11-13]. Subsequent work identified several isoforms of these enzymes in human and mouse, which are generated from a single gene as a result of alternative exon usage [14, 15]. These gene products contain an alternative first exon, with the remaining eight 
exons being identical in each gene product, resulting in four different isoforms with different amino-terminal ends. The resultant gene products are localized in both cytosol and mitochondria, and possibly nucleus [14]. Expression of these enzymes is remarkably high in brain and testis, and in human brain they account for over $75 \%$ of the thioesterase activity found in this tissue [16]. In human brain, these proteins are expressed in neurons e.g pyramidal cells in the cerebral cortex and Purkinje cells in the cerebellum [14]. In developing mouse brain, Type-II acyl-CoA thioesterases were shown to be expressed during embryogenesis in association with neuronal differentiation [17] and in adult mouse brain, these enzymes are exclusively localized to neurons [15]. The Type-II acyl-CoA thioesterases have a broad substrate specificity, and can hydrolyze acyl-CoAs from C6-C20-CoA, together with C18:1-CoA, C18:2-CoA and C20:4-CoA [10, 11, $13,16,18]$.

Tremendous progress has been made in recent years regarding identification of defective enzymes in fatty acid oxidation (FAO) disorders. These are a group of inherited diseases that result from defects in enzymes involved in either mitochondrial or peroxisomal $\square$-oxidation, or alternatively in transport proteins in these organelles $[19,20]$. However, no work has been carried out on identification of possible deficiencies/defects in acyl-CoA thioesterases, despite their activity and presence in mitochondria and peroxisomes. This study was therefore undertaken to screen patients for possible defects in acyl-CoA thioesterases.

\section{Materials and methods}




\section{Culture of fibroblasts}

Primary skin fibroblasts were obtained from healthy control subjects and patients with an apparent but unknown defect in mitochondrial fatty acid oxidation as concluded from the finding of an abnormal pamitate loading test [21], showing elevated palmitoyl-carnitine levels, whereas measurement of candidate enzymes like carnitine/acylcarnitine translocase (CACT), carnitine palmitoyl transferase II, and very-long-chain acyl-CoA dehydrogenase (VLCAD) showed normal activities. Fibroblasts were cultured in HAM F-10 medium (Gibco BRL) containing 10\% fetal calf serum and 1\% penicillin/streptomycin at $37^{\circ} \mathrm{C}$ in a humidified atmosphere in $5 \% \mathrm{CO}_{2}$. Ethical permission is held for use of patient fibroblasts in this study.

\section{Measurement of acyl-CoA thioesterase activity}

Fibroblasts were harvested, sonicated $3 \times 10 \mathrm{sec}$ in phosphate buffered saline (PBS) and centrifuged for $1 \mathrm{~min}$ at $14,000 \mathrm{X}$ g. The supernatant was used for measurement of acyl-CoA thioesterase activity. The medium contained $200 \mathrm{mM}$ potassium chloride, $10 \mathrm{mM}$ Hepes and $0.05 \mathrm{mM}$ 5,5'-dithiobis(2-nitrobenzoic) acid (DTNB), pH 7.4. The medium was pre-incubated with fibroblast homogenate for $5 \mathrm{~min}$ at $37^{\circ} \mathrm{C}$. The reaction was started with addition of $50 \square \mathrm{M}$ of acyl-CoA substrate. Measurements were carried out spectrophotometrically in a Cobas Fara II Centrifugal Analyzer (Hoffmann - La Roche, Basel, Switzerland) at $412 \mathrm{~nm}$. An $\mathrm{E}_{412}=13,600 \mathrm{M}^{-1} \mathrm{~cm}^{-1}$ was used to calculate the activity.

\section{Fractionation of human skin fibroblasts}


Fibroblasts from healthy controls were washed in $0.5 \mathrm{ml}$ ice-cold SEM buffer (containing $250 \mathrm{mM}$ sucrose, $1 \mathrm{mM}$ EDTA and $5 \mathrm{mM}$ MOPS, $\mathrm{pH}$ 7.4) and resuspended in fresh SEM buffer $(0.5 \mathrm{ml})$. Cells were lysed using an 8,020 cell cracker (EMBL, Heidelberg) and an $8.008 \mathrm{~mm} \square$ ball (6 $\square \mathrm{m}$ gap). The cells were passed through the cell cracker 6 times and centrifuged at 2,000 X $\mathrm{g}$ for $5 \mathrm{~min}$ at $4^{\circ} \mathrm{C}$. The pellet was resuspended in $0.5 \mathrm{ml}$ SEM and the procedure repeated. The supernatants were combined, 0.5 mM PMSF was added and the sample incubated on ice for several minutes. The supernatant was loaded onto a continuous Nycodenz density gradient and centrifuged at $19,000 \mathrm{X} \mathrm{g}$ for $2.5 \mathrm{~h}$ at $4^{\circ} \mathrm{C}$. Fractions $(0.5 \mathrm{ml})$ were collected and marker enzyme activities were measured for catalase (peroxisomes) [22], lactate dehydrogenase (cytosol) [23] and glutamate dehydrogenase (mitochondria) [24]. Acyl-CoA thioesterase activity was measured as above, using $50 \square \mathrm{M}$ palmitoyl-CoA.

\section{Digitonin treatment of human skin fibroblasts}

A pilot experiment to determine the optimal digitonin concentration to separate cytosol and pellet fractions in skin fibroblasts was carried out, and was determined to be $100 \mathrm{gg} / \mathrm{ml}$ digitonin. Fibroblast pellets were resuspended in SEM to approximately $1 \mathrm{mg} / \mathrm{ml}$ protein. $100 \mathrm{\square g} / \mathrm{ml}$ digitonin was added to each cell pellet, mixed and incubated on ice for $30 \mathrm{~min}$. Cells were centrifuged at 5,000 $\mathrm{X} g$ at $4^{\circ} \mathrm{C}$ for $2 \mathrm{~min}$. The supernatant was removed and $4 \square 1$ of $10 \%$ Triton X-100 was added. The pellet was resuspended in $400 \square$ SEM buffer and $4 \square 1$ 10\% triton was added. Marker enzymes LDH and GDH, and acyl-CoA thioesterase activity were measured as outlined above. 


\section{Antibody preparation and Western blot analysis}

A peptide was synthesized based on the amino acid sequence of the $\mathrm{COOH}$ terminal end of the rat cytosolic acyl-CoA thioesterase II (CTE-II) cDNA [11] CKAKRQGHTEPQP-OH (with a cysteine added at the amino-terminal end for coupling of the peptide), which differs only in one amino acid from the human sequence and will recognize all human isoforms of the Type-II gene family. Fibroblast protein concentration was determined using bicinchoninic acid (BCA) and measured at $562 \mathrm{~nm}$ using ELISA. $50 \square \mathrm{g}$ of fibroblast protein was separated on a 10\% SDS/PAGE gel and transferred to a nitrocellulose membrane using a semi-dry blotting system (Amersham). Western blot analysis was carried out as described [25], using the rat anti-CTE-II antibody.

\section{Immunoprecipitation using an antibody to Type-II acyl-CoA thioesterases}

An experiment was carried out to determine the optimum concentration of antiCTE-II antibody required for immunoprecipitation of Type-II acyl-CoA thioesterase activity in skin fibroblasts. Various volumes (5, 10, 20 and $40 \square 1$ ) of the affinity purified anti-Type-II antibody were incubated overnight in an orbital shaker at $4^{\circ} \mathrm{C}$ in $0.1 \%$ Triton X-100/PBS, together with Protein A Sepharose beads (Sigma Corp). A control reaction was carried out using pre-immune serum in place of anti-CTE-II antibody. Fibroblast suspensions were incubated with Protein A Sepharose/anti-CTE-II antibody for $2 \mathrm{~h}$ at $4^{\circ} \mathrm{C}$. The samples were centrifuged at $14,000 \mathrm{Xg}$ for $1 \mathrm{~min}$ at $4^{\circ} \mathrm{C}$ and acyl-CoA thioesterase activity was determined in the supernatant. 
Ten $\square$ l of antibody was sufficient to precipitate the Type-II acyl-CoA thioesterase activity. Both control and fibroblasts from patient No. 3 and No. 5 were immunoprecipitated with $10 \square 1$ antibody and acyl-CoA thioesterase activity determined.

\section{Results}

\section{Acyl-CoA thioesterase activity in human skin fibroblasts}

Acyl-CoA thioesterase activity was determined in fibroblast homogenates using butyryl-CoA (C4:0), hexanoyl-CoA (C6:0), octanoyl-CoA (C8:0), decanoyl-CoA (C10:0), lauroyl-CoA (C12:0), myristoyl-CoA (C14:0), palmitoyl-CoA (C16:0) and

stearoyl-CoA (C18:0). Fibroblasts showed acyl-CoA thioesterase activity with all tested acyl-CoAs, however, the activity with short chain acyl-CoAs was considerably lower than with medium or long-chain acyl-CoAs. Maximum activity was measurable with myristoyl-CoA and palmitoyl-CoA (C14:0-CoA and C16:0-CoA respectively) (Fig. 1).

To determine which cellular compartment contains the majority of acyl-CoA thioesterase activity, human skin fibroblasts were fractionated and marker enzymes for cytosol (lactate dehydrogenase - LDH), mitochondria (glutamate dehydrogenase - GDH) and peroxisomes (catalase) were measured (Fig 2A-C). LDH was found mainly in fractions 10-20 representing cytosol, whereas GDH was mainly detected in fractions 7 and 8, representing mitochondrial-enriched fractions. Two peaks of catalase were identified in fractions 4-8 (peroxisomes) 
and also in fractions 14-18 containing cytosol. Acyl-CoA thioesterase activity was measured in the fractions using C16:0-CoA as substrate (Fig. 2D). The majority of acyl-CoA thioesterase activity was found in the cytosolic fractions (fractions 1520), with some detectable activity in fractions 7 and 8 containing mitochondrialenriched fractions.

The major acyl-CoA thioesterase activity in fibroblasts is catalyzed by Type-II acyl-CoA thioesterases

Type-II acyl-CoA thioesterases have been shown to hydrolyze a broad range of acyl-CoAs, ranging from C6:0-C20:0-CoA $[11-13,15,16]$. This pattern was in line with the thioesterase activity identified in fibroblasts. In order to determine if the thioesterase activity in fibroblasts is due to the Type-II enzymes, immunoprecipitation experiments were carried out using an antibody to the rat CTE-II [11], which will recognize all human isoforms of the Type-II enzymes [14]. Immunoprecipitation with this antibody resulted in precipitation of almost all acyl-CoA thioesterase activity in fibroblasts with C8:0-CoA, C12:0-CoA and C14:0-CoA (Fig 3). However the butyryl-CoA (C4:0-CoA) activity, although extremely low, was not precipitated even at the highest antibody concentration (data not shown), suggesting that this activity is catalyzed by another short-chain acyl-CoA thioesterase.

\section{Detection of patients with lowered Type-II thioesterase activity and protein.}

Approximately 40 patient cell lines were selected based on abnormal palmitoylcarnitine levels following palmitate-loading test [21]. Initial screening was 
carried out using frozen pellets of fibroblasts from these patients. From this screening, 5 patient cell lines appeared to have lowered acyl-CoA thioesterase activity with substrates ranging from $\mathrm{C} 6: 0-\mathrm{C} 18: 0-\mathrm{CoA}$. These cell lines were then cultured to obtain fresh fibroblasts for further experiments.

Western blot analysis was carried out on total fibroblast homogenates from these 5 patients to examine Type-II acyl-CoA thioesterase protein levels. The Type-II antibody recognized one major band at approx $40 \mathrm{kDa}$, which represents both cytosolic and mitochondrial isoforms of these thioesterases [14]. Of the 5 patients identified, only 3 of these patients (patients 1, 3 and 5) had lowered Type-II protein levels (Fig. 4A). The same blot was stripped and re-probed with an antibody generated to the mitochondrial short chain 3-hydroxyacyl-CoA dehydrogenase (SCHAD) [26], showing that this protein was unaffected in the patients. Quantitation of the protein levels relative to control showed that patients 1 and 3 retained approximately 25-30\% Type-II protein, however patient 5 retained only $10 \%$ of Type-II protein (Fig. 4B).

Acyl-CoA thioesterase activity was then measured in fibroblasts from patients 1 , 3 and 5, using acyl-CoAs of C4:0-C18:0-CoA (Fig. 5). These patients retained approximately $30 \%$ residual acyl-CoA thioesterase activity with substrates from C6:0-C18:0-CoA, with patient 5 showing the lowest activity for all substrates tested. To determine if the residual thioesterase activity in these patients was catalyzed by Type-II thioesterases, immunoprecipitation was carried out on fibroblasts from a healthy control and 2 patients (No. 3 and No. 5). Immunoprecipitation with the Type-II antibody resulted in precipitation of all 
the residual acyl-CoA thioesterase activity in both patients' fibroblasts with C14:0-CoA (Fig. 6A), C12:0-CoA (Fig. 6B) and C8:0-CoA (Fig. 6C).

As the major isoforms of Type-II acyl-CoA thioesterases are expressed in both cytosol and mitochondria, digitonin treatment of human skin fibroblasts was carried out to determine if the lowered acyl-CoA thioesterase activity identified in patients was confined to a particular cellular compartment. Marker enzymes for cytosol (LDH) and mitochondria (GDH) showed that the supernatant (containing cytosol) was relatively devoid of the mitochonrial enzyme GDH and that the pellet fraction (containing organelles) was almost devoid of the cytosolic marker LDH (Fig. 7A). Measurement of acyl-CoA thioesterase activity for controls and patient No. 5 showed that this patient had lowered thioesterase activity towards $\mathrm{C} 8: 0-\mathrm{CoA}, \mathrm{C} 10: 0-\mathrm{CoA}$ and $\mathrm{C} 12: 0-\mathrm{CoA}$ in the supernatant (representing the cytosol) (Fig. 7B). However, this patient also showed lowered acyl-CoA thioesterase activity towards $\mathrm{C} 10: 0-\mathrm{CoA}$ and $\mathrm{C} 12: 0-\mathrm{CoA}$ in the pellet fraction (mainly representing mitochondrial activity) (Fig. 7C).

\section{Genetic analysis of cDNA from patients with lowered acyl-CoA thioesterase activity. \\ cDNA was isolated from patients 1,3 and 5 and both the CTE-II and mitochondrial acyl-CoA thioesterase II (MTE-II) cDNAs were fully sequenced. However, sequencing analysis failed to identify any mutation in the coding region (data not shown).}

\section{Discussion}


Several different families of acyl-CoA thioesterases have been identified in a variety of species. Although many of these enzymes have been characterized in detail, patients with possible deficiencies in acyl-CoA thioesterases have yet to be identified. One thioesterase that has been associated with neurodegenerative diseases is the palmitoyl protein thioesterase 1 (PPT) (for review see [27]). Mutations in PPT1, a lysosomal enzyme that removes fatty acyl groups from cysteine residues in modified proteins, causes the fatal infantile neuronal ceroid lipofuscinosis (INCL). In an effort to address the question regarding identification of patients defective in acyl-CoA thioesterases, we carried out screening of 40 patients with suspected fatty acid oxidation deficiencies. These patients presented with symptoms of fatty acid oxidation disorders and loading of fibroblasts with palmitate led to the finding of increased palmitoyl carnitine levels, whereas candidate enzymes such as carnitine/acylcarnitine translocase (CACT), carnitine palmitoyl transferase II (CPTII), and very long chain acyl-CoA dehydrogenase (VLCAD), showed normal activities. We established a screening method for acyl-CoA thioesterase activity in these patient fibroblasts using a spectrophotometric method. Measurement of acyl-CoA thioesterase activity was variable in frozen fibroblast pellets, and therefore the use of freshly cultured fibroblasts was optimal. The major acyl-CoA thioesterase activity measurable in human skin fibroblasts results from Type-II thioesterases, as seen by the immunoprecipitation assay. This limits the use of enzymatic activity analysis in screening for patients deficient in other families of acyl-CoA thioesterases, such as Type-I acyl-CoA thioesterases [28, 29]. A further complication is the overlapping substrate specificities for these families of acyl-CoA thioesterases, as both these Type-I $[18,30]$ and Type-II families hydrolyze long chain acyl-CoAs 
$[10,11,13,16,18]$ and the high level of Type-II acyl-CoA thioesterase activity in fibroblasts may mask any Type-I thioesterase activity.

The specific functions of Type-II acyl-CoA thioesterases have not been elucidated, but given their very high expression in brain and testis, it has been hypothesized that they could be involved in steroidogenic processes. It has previously been shown that over-expression of CTE-II does not result in any change in phospholipids synthesis in cultured cells [11, 31], however this overexpression appeared to be toxic to cultured cells [31]. Given that Type-II acylCoA thioesterases show very high expression in human brain, it may be hypothesized that lowered Type-II thioesterase protein may affect brain function. Patient 5, who showed the lowest acyl-CoA thioesterase protein level, has a neurological syndrome with marked neurological deterioration including cerebellar dysplasia. Notably, the three patients retained some residual protein expression and activity of Type-II acyl-CoA thioesterases, which shows that they do not have a complete deficiency of Type-II activity. Western blot confirmed that the size of the Type-II protein in patients is identical to that of healthy controls, suggesting that there may be a defective translational regulation of Type-II proteins in patients, or alternatively that a promotor mutation may exist which may impair proper transcription.

In human, four different isoforms of Type-II thioesterases have been identified, which are a result of alternative exon usage from the same gene on chromosome 1p36.2 [14]. These isoforms are expressed in cytosol, mitochondria and possibly also nucleus. Mutation analysis on the coding sequence for CTE-II and MTE-II of 
the patients identified in this study failed to identify any mutations, however, a promotor mutation would result in altered transcription levels of all isoforms of Type-II thioesteraes encoded by a single gene. The digitonin experiments (Fig. 7B and 7C) support this hypothesis as patient 5 had lowered acyl-CoA thioesterase activity in both supernatant (cytosol) and pellet (mitochondria) fraction. Two further isoforms of Type-II thioesterases, which can be encoded from the same gene, contain an additional exon (exon $\mathrm{X}$ ), which results in a premature stop codon and a truncated protein. It was speculated that expression of isoforms containing exon $\mathrm{X}$-derived sequences may reflect pathological conditions, however, this remains to be determined.

In conclusion, we undertook to identify the first patients with deficiencies in acyl-CoA thioesterases. We have identified 3 patients with lowered Type-II acylCoA thioesterase protein and activity, however we did not detect any mutations in the coding region of the MTE-II or CTE-II. Further work is required in this regard, which is currently underway. 
Figure legends:

Fig. 1: Measurement of acyl-CoA thioesterase activity in human skin fibroblasts. Acyl-CoA thioesterase activity was measured in human skin fibroblast homogenates using $50 \square \mathrm{M}$ of various acyl-CoA substrates. C4:0, butyryl-CoA; C6:0, hexanoyl-CoA; C8:0, octanoyl-CoA; C10:0, decanoyl-CoA; C12:0, lauroyl-CoA; C14:0, myristoyl-CoA; C16:0, palmitoyl-CoA; C18:0, stearoyl-CoA.

Fig. 2: Fractionation of human skin fibroblasts. Human skin fibroblasts were fractionated as described in Materials and methods. Marker enzymes for (A) cytosol (lactate dehydrogenase - LDH) (B) mitochondria (glutamate dehydrogenase - GDH) and (C) peroxisomes (catalase) were measured in each fraction. (D) Acyl-CoA thioesterase activity was measured in each fraction using $50 \square \mathrm{M}$ palmitoyl-CoA (C16-CoA).

Fig. 3: Type-II acyl-CoA thioesterases are the major thioesterase enzymes in human skin fibroblasts. Immunoprecipitation of acyl-CoA thioesterase activity was carried out by incubating human skin fibroblast homogenate with either pre-immune serum or an affinity-purified antibody to CTE-II. The remaining acyl-CoA thioesterase activity was measured in the supernatant with various acyl-CoA substrates. C4:0, butyryl-CoA; C8:0, octanoyl-CoA; C12:0, lauroyl-CoA; C14:0, myristoyl-CoA. 
Fig. 4: Identification of 3 patients with lowered Type-II acyl-CoA thioesterase protein. (A) Western blot analysis was carried out on $50 \square \mathrm{g}$ of fibroblast homogenate protein from 3 controls and 5 patients. The filter was incubated with an affinity purified Type-II antibody. Mouse testis was used as a positive control. The filter was stripped and re-probed with an antibody to short chain 3hydroxyacyl-CoA dehydrogenase (SCHAD). (B) Quantitation of Western blot analysis for Type-II acyl-CoA thioesterases. The mean of three individual control values was set to $100 \%$ and patient protein levels are expressed as $\%$ of control.

Fig. 5: Acyl-CoA thioesterase activity in patients. Acyl-CoA thioesterase activity was measured in freshly grown human skin fibroblasts, using $50 \square \mathrm{M}$ acyl-CoAs from C4:0-CoA to C18:0-CoA (see Fig. 1 for abbreviations). Control is shown as a mean of 3 individual controls \pm S. E. M. Activities were measured in three different experiments and a representative experiment is shown.

Fig. 6. The residual acyl-CoA thioesterase activity in patients is catalyzed by Type-II thioesterases. Immunoprecipitation of acyl-CoA thioesterase activity was carried out by incubating human skin fibroblast homogenate from a healthy control or patient No. 3 and No. 5 with either pre-immune serum or an affinitypurified antibody to CTE-II. The remaining acyl-CoA thioesterase activity was measured in the supernatant with (A) myristoyl-CoA (C14:0), (B) lauroyl-CoA (C12:0) and (C) octanoyl-CoA (C8:0). 
Fig. 7: Digitonin treatment of human skin fibroblasts. Human skin fibroblasts were treated with $100 \square \mathrm{g} / \mathrm{ml}$ digitonin as described in Materials and methods. (A) Lactate dehydrogenase (LDH - cytosol) and glutamate dehydrogenase (GDH - mitochondria) activities were measured in the supernatant and pellet fractions. (B) Acyl-CoA thioesterase activity was measured in both control and patient No. 5 supernatant fractions using C8:0, octanoyl-CoA; C10:0, decanoyl-CoA and C12:0, lauroyl-CoA. (C) Acyl-CoA thioesterase activity was measured in both control and patient No 5 pellet fractions using C10:0, decanoyl-CoA and C12:0, lauroyl-CoA. Control values are mean of 2 individual controls \pm range (supernatant) and 3 individual controls \pm S. E. M. (pellet). 


\section{References}

1. Hunt, M. C. \& Alexson, S. E. H. (2001) The role acyl-CoA thioesterases play in mediating intracellular lipid metabolism., Prog. Lipid Res. 41, 99-130.

2. Knudsen, J., Jensen, M. V., Hansen, J. K., Færgeman, N. J., Neergaard, T. B. F. \& Gaigg, B. (1999) Role of acyl-CoA binding protein in acyl-CoA transport, metabolism and cell signaling, Mol. Cell. Biochem. 192, 95-103.

3. Bränström, R., Aspinwall, C. A., Välimäki, S., Östensson, C.-G., Tibell, A., Eckhard, M., Brandhorst, H., Corkey, B. W., Berggren, P.-O. \& Larsson, O. (2004) Long-Chain CoA esters activate human pancreatic beta-cell KATP channels:potential role in Type 2 diabetes., Diabetologia. 47, 277-283.

4. Kliewer, S. A., Sundseth, S. S., Jones, S. A., Brown, P. J., Wisely, G. B., Koble, C. S., Devchand, P., Wahli, W., Willson, T. M., Lenhard, J. M. \& Lehmann, J. M. (1997) Fatty acids and eicosanoids regulate gene expression through direct interactions with peroxisome proliferators-activated receptors $\square$ and $\square$ Proc. Natl. Acad. Sci. U.S.A. 94, 4318-4323.

5. Forman, B. M., Chen, J. \& Evans, R. M. (1997) Hypolipidemic drugs, polyunstaurated fatty acids, and eicosanoids are ligands for peroxisome proliferator-activated receptors $\square$ and $\square$ Proc. Natl. Acad. Sci. U.S.A. 94, 43124317.

6. Göttlicher, M., Widmark, E., Li, Q. \& Gustafsson, J.-Å. (1992) Fatty acids activate a chimera of the clofibric acid-activated receptor and the glucocorticoid receptor, Proc. Natl. Acad. Sci. U.S.A. 89, 4653-4657.

7. Elholm, M., Dam, I., Jørgensen, C., Krogsdam, A.-M., Holst, D., Kratchmarova, I., Göttlicher, M., Gustafsson, J.-Å., Berge, R., Flatmark, T., Knudsen, J., Mandrup, S. \& Kristiansen, K. (2001) Acyl-CoA esters antagonize the effects of ligands on PPAR $\square$ confirmation, DNA binding and interaction with co-factors., J. Biol. Chem. 276, 21410-21416.

8. Hertz, R., Magenheim, J., Berman, I. \& Bar-Tana, J. (1998) Fatty acyl-CoA thioesters are ligands of hepatic nuclear factor-4 $\square$, Nature. 392, 512-516.

9. Færgeman, N. J. \& Knudsen, J. (1997) Role of long-chain acyl-CoA esters in the regulation of metabolism and in cell signalling., Biochem. J. 323, 1-12.

10. Miyazawa, S., Furuta, S. \& Hashimoto, T. (1981) Induction of a novel longchain acyl-CoA hydrolase in rat liver by administration of peroxisome proliferators, Eur. J. Biochem. 117, 425-430.

11. Engberg, S. T., Aoyama, T., Alexson, S. E. H., Hashimoto, T. \& Svensson, L. T. (1997) Peroxisome proliferator-induced acyl-CoA thioesterase from rat liver cytosol: molecular cloning and functional expression in Chinese hamster ovary cells, Biochem. J. 323, 525-531.

12. Yamada, J., Furihata, T., Iida, N., Watanabe, T., Hosokawa, M., Satoh, T., Someya, A., Nagaoka, I. \& Suga, T. (1997) Molecular cloning and expression of cDNAs encoding rat brain and liver cytosolic long-chain acyl-CoA hydrolases, Biochem. Biophys. Res. Commun. 232, 198-203.

13. Broustas, C. G., Larkins, L. K., Uhler, M. D. \& Hajra, A. K. (1996) Molecular cloning and expression of cDNA encoding rat brain cytosolic acyl-coenzyme A thioester hydrolase, J. Biol. Chem. 271, 10470-10476. 
14. Yamada, J., Kuramochi, Y., Takagi, M., Watanabe, T. \& Suga, T. (2002) Human brain acyl-CoA hydrolase isoforms encoded by a single gene., Biochem. Biophys. Res. Comm. 299, 49-56.

15. Kuramochi, Y., Takagi-Sakuma, M., Kitahara, M., Emori, R., Asaba, Y., Sakaguchi, R., Watanabe, T., Kuroda, J., Hiratsuka, K., Nagae, Y., Suga, T. \& Yamada, J. (2002) Characterization of mouse homolog of brain acyl-CoA hydrolase: molecular cloning and neuronal localization., Mol. Brain Res. 98, 81-92. 16. Yamada, J., Kurata, A., Hirata, M., Taniguchi, T., Takama, H., Furihata, T., Shiratori, K., Iida, N., Takagi-Sakuma, M., Watanabe, T., Kurosaki, K., Endo, T. \& Suga, T. (1999) Purification, molecular cloning, and genomic organization of human brain long-chain acyl-CoA hydrolase., J. Biochem. 126, 1013-1019.

17. Yamada, J., Kuramochi, Y., Takagi, M. \& Suga, T. (2004) Expression of acylCoA hydrolase in the developing mouse brain., Neurosci. Lett. 355, 89-92.

18. Svensson, L. T., Alexson, S. E. H. \& Hiltunen, J. K. (1995) Very long chain and long chain acyl-CoA thioesterases in rat liver mitochondria. Identification, purification, characterization, and induction by peroxisome proliferators, J. Biol. Chem. 270, 12177-12183.

19. Wanders, R. J. A., Vreken, P., Den Boer, M. E. J., Wijburg, F. A., Van Gennip, A. H. \& Ljlst, L. (1999) Disorders of mitochondrial fatty acyl-CoA beta-oxidation., J. Inherit. Metab. Dis. 22, 422-487.

20. Wanders, R. J. A. (2004) Metabolic and Molecular Basis of Peroxisomal Disorders: A review., Am. J. Hum. Genet. 126A, 355-375.

21. Ventura, F. V., Costa, C. G., Struys, E. A., Ruiter, J., Allers, P., Ijlst, L., Tavares de Almeida, I., Duran, M., Jakobs, C. \& Wanders, R. J. A. (1999) Quantitative acylcarnitine profiling in fibroblasts using [U-13-C] palmitic acid: an improved tool for the diagnosis of fatty acid oxidation defects., Clin. Chim. Acta. 281, 1-17. 22. Wanders, R. J. A., Denis, S., Wouters, F., Wirtz, K. W. A. \& Seedorf, U. (1997) Sterol carrier protein $\mathrm{X}(\mathrm{SCPx})$ is a peroxisomal branched-chain $\mathrm{G}$-ketothiolase specifically reacting with 3-oxo-pristanoyl-CoA: a new, unique role for SCPx in branched-chain fatty acid metabolism in peroxisomes., Biochem. Biophys. Res. Comm. 236, 565-569.

23. Verhoeven, N. M., Wanders, R. J. A., Schor, D. S. M., Jansen, G. A. \& Jakobs, C. (1997) Phytanic acid Q-oxidation: decarboxylation of 2-hydroxyphytanoylCoA to pristanic acid in human liver., J. Lipid Res. 38, 2062-2070.

24. Wanders, R. J. A., van Roermund, C. W., de Vries, C. T., Van den Bosch, H., Schrakamp, G., Tager, J. M., Schram, A. W. \& Schutgens, R. B. H. (1986)

Peroxisomal b-oxidation of palmitoyl-CoA in human liver homogenates and its deficiency in the cerebro-hepatorental (Zellweger) syndrome., Clin. Chim. Acta. 159, 1-10.

25. Hunt, M. C., Lindquist, P. J. G., Peters, J. M., Gonzalez, F. J., Diczfalusy, U. \& Alexson, S. E. H. (2000) Involvement of the peroxisome proliferator-activated receptor alpha (PPAR $\square$ ) in regulation of long chain acyl-CoA thioesterases, J. Lipid Res. 41, 814-823.

26. Bennett, M. J., Spotswood, S. D., Ross, K. F., Comfort, S., Koonce, R., Boriack, R. L., IJlst, L. \& Wanders, R. J. A. (1999) Fatal hepatic short-chain L-3hydroxyacyl-coenzyme A dehydrogenase deficiency: Clinical, biochemical, and pathological studies on three subjects with this recently identified disorder of mitochondrial b-oxidation., Ped. Dev. Pathol. 4, 337-345. 
27. Mitchison, H. M. \& Mole, S. E. (2001) Neurodegenerative disease: the neuronal ceroid lipofuscinoses (Batten disease). Curr. Opin. Neuro. 14, 795-803. 28. Hunt, M. C., Nousiainen, S. E. B., Huttunen, M. K., Orii, K., Svensson, L. T. \& Alexson, S. E. H. (1999) Peroxisome proliferator-induced long chain acyl-CoA thioesterases comprise a highly conserved novel multi-gene family involved in lipid metabolism, J. Biol. Chem. 274, 34317-34326.

29. Westin, M. A., Alexson, S. E. H. \& Hunt, M. C. (2004) Molecular cloning and characterization of two mouse peroxisome proliferator-activated receptor alpha (PPARalpha)-regulated peroxisomal acyl-CoA thioesterases., J. Biol. Chem. 279, 21841-21848.

30. Huhtinen, K., O'Byrne, J., Lindquist, P. J. G., Contreras, J. A. \& Alexson, S. E. H. (2002) The peroxisome proliferator-induced cytosolic type I acyl-CoA thioesterase (CTE-I) is a serine-histidine-aspartic acid alpha/beta hydrolase., $J$. Biol. Chem. 277, 3424-3432.

31. Takagi, M., Yamakawa, H., Watanabe, T., Suga, T. \& Yamada, J. (2003) Inducible expression of long-chain acyl-CoA hydrolase gene in cell cultures., Mol. Cell. Biochem. 252, 379-385. 
Fig. 1

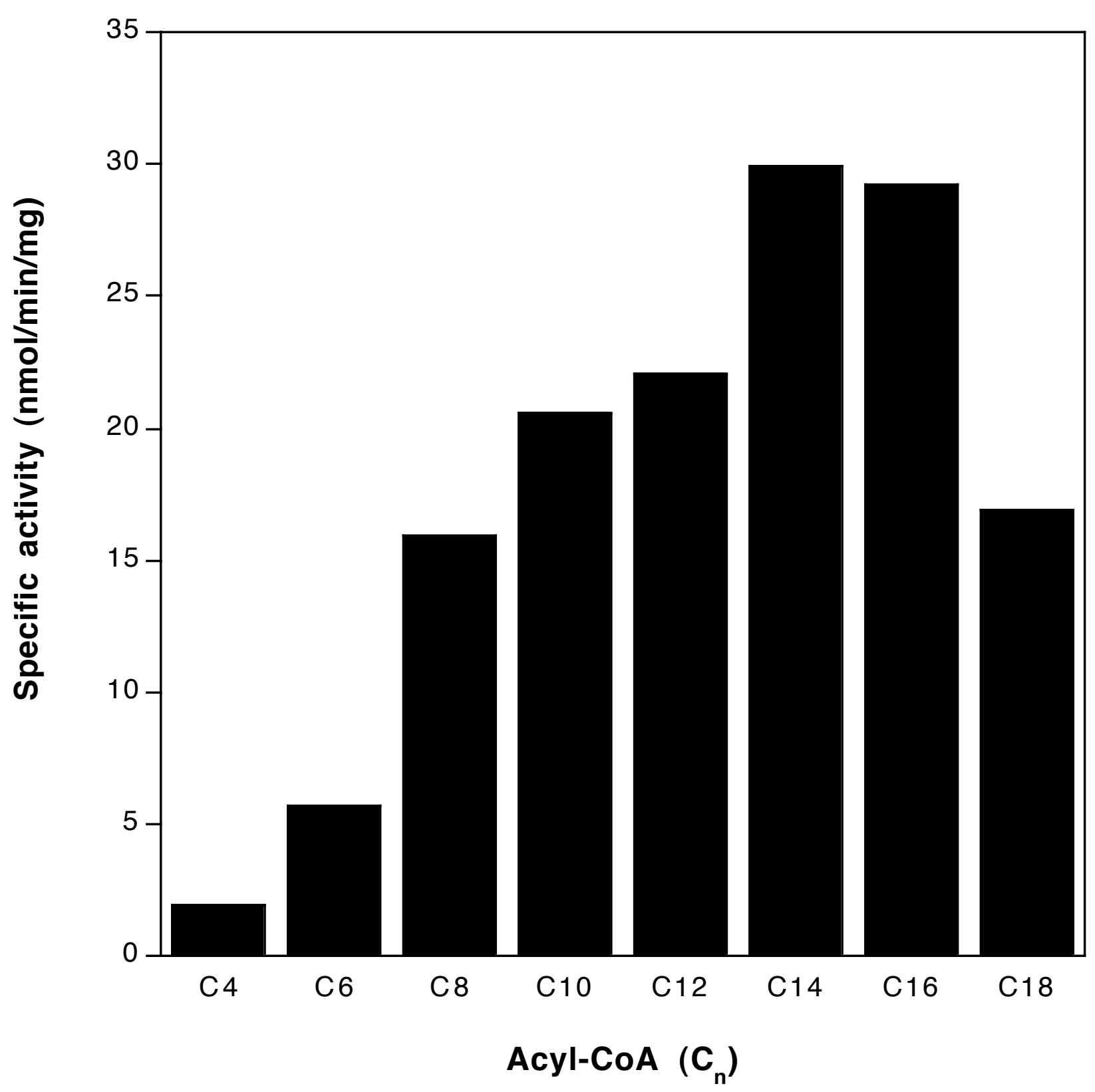


Fig. 2

A



C

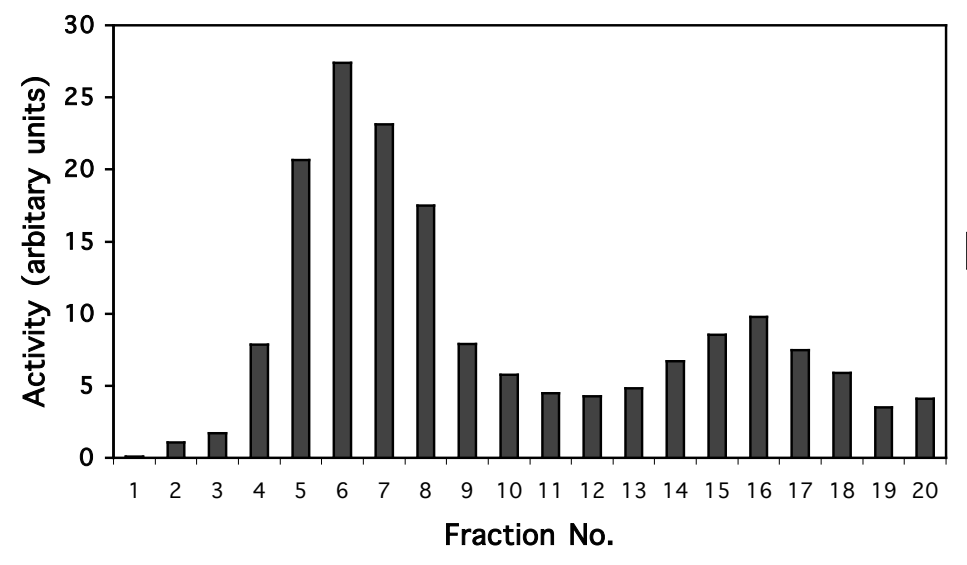

B

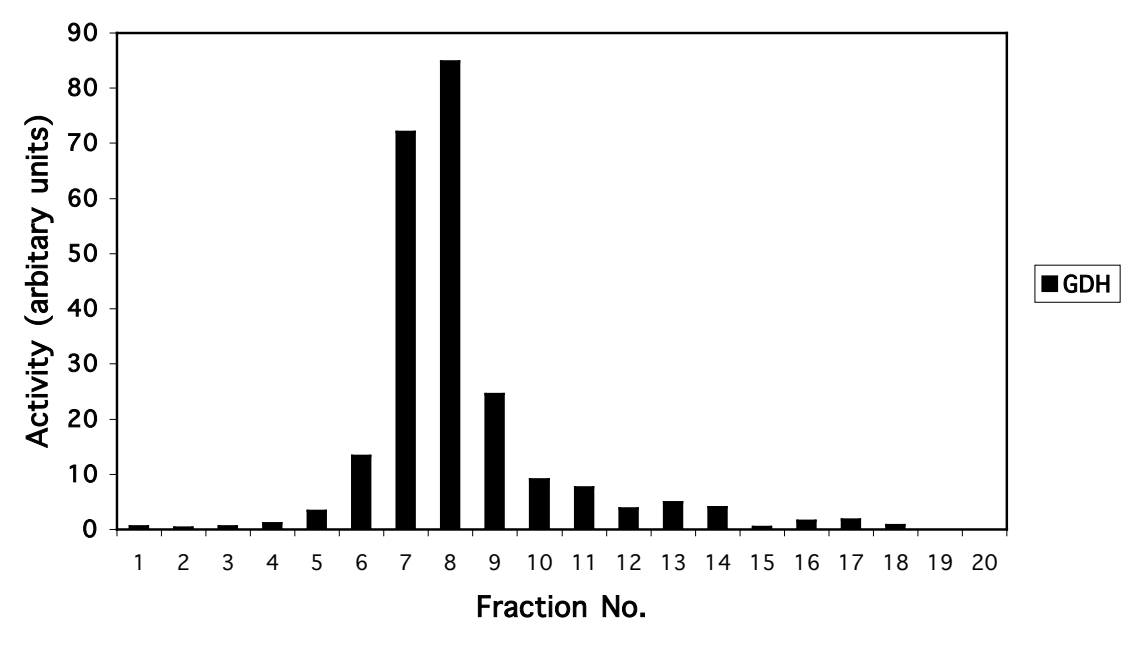

D

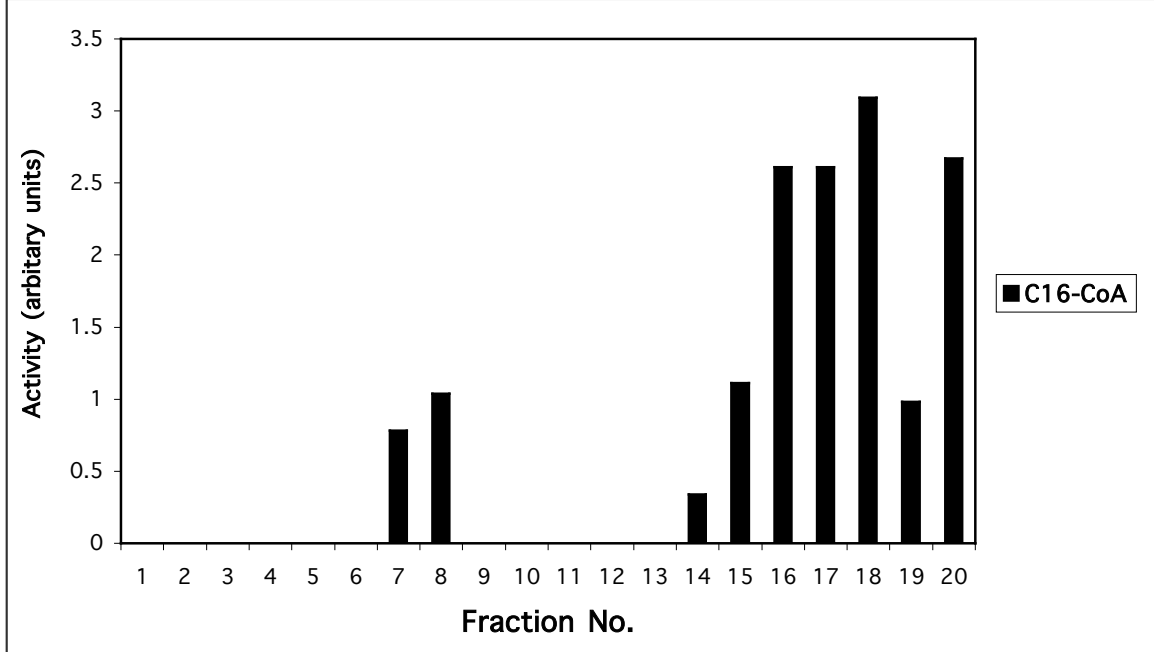


Fig. 3

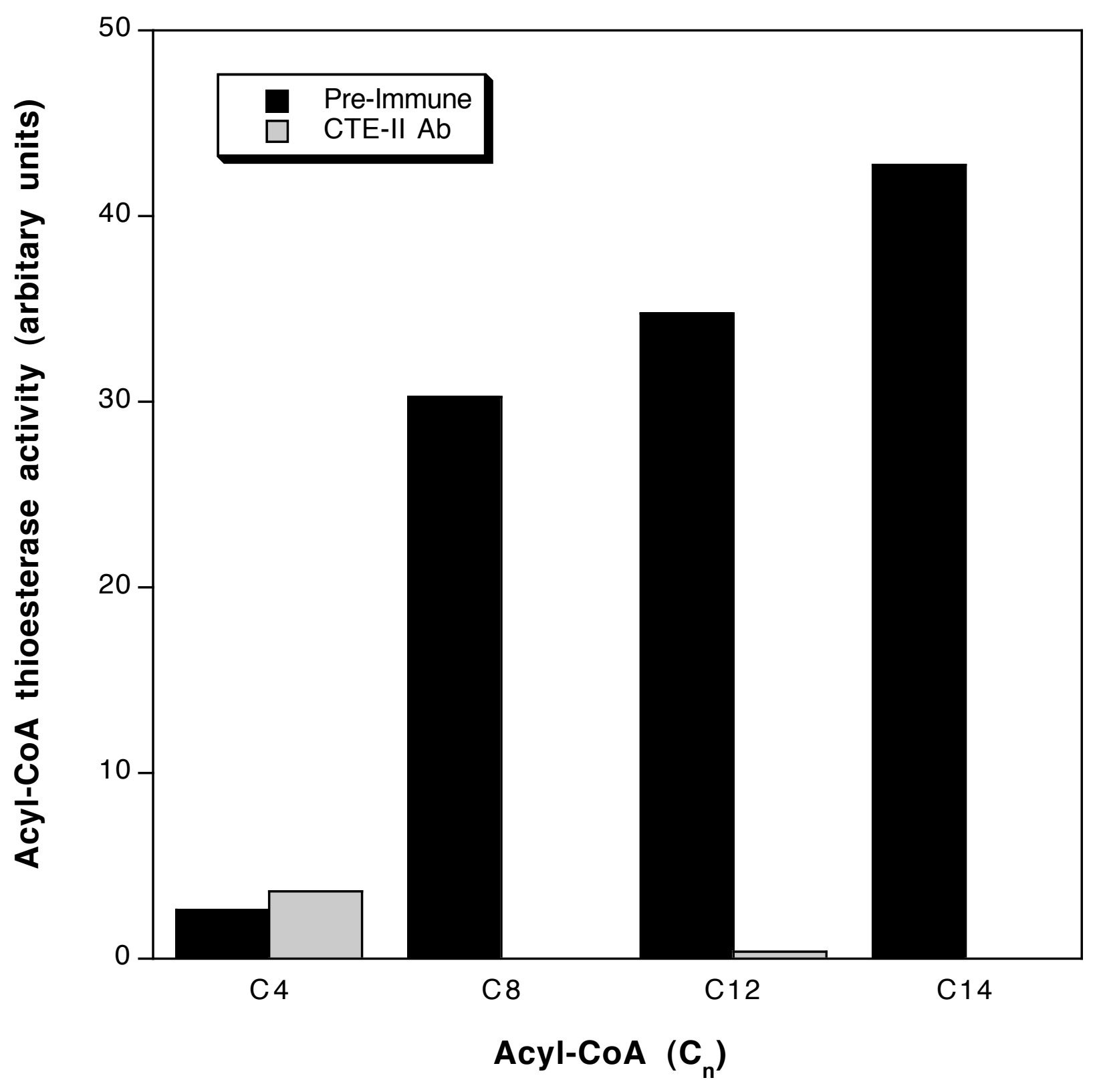


Fig. 4

A

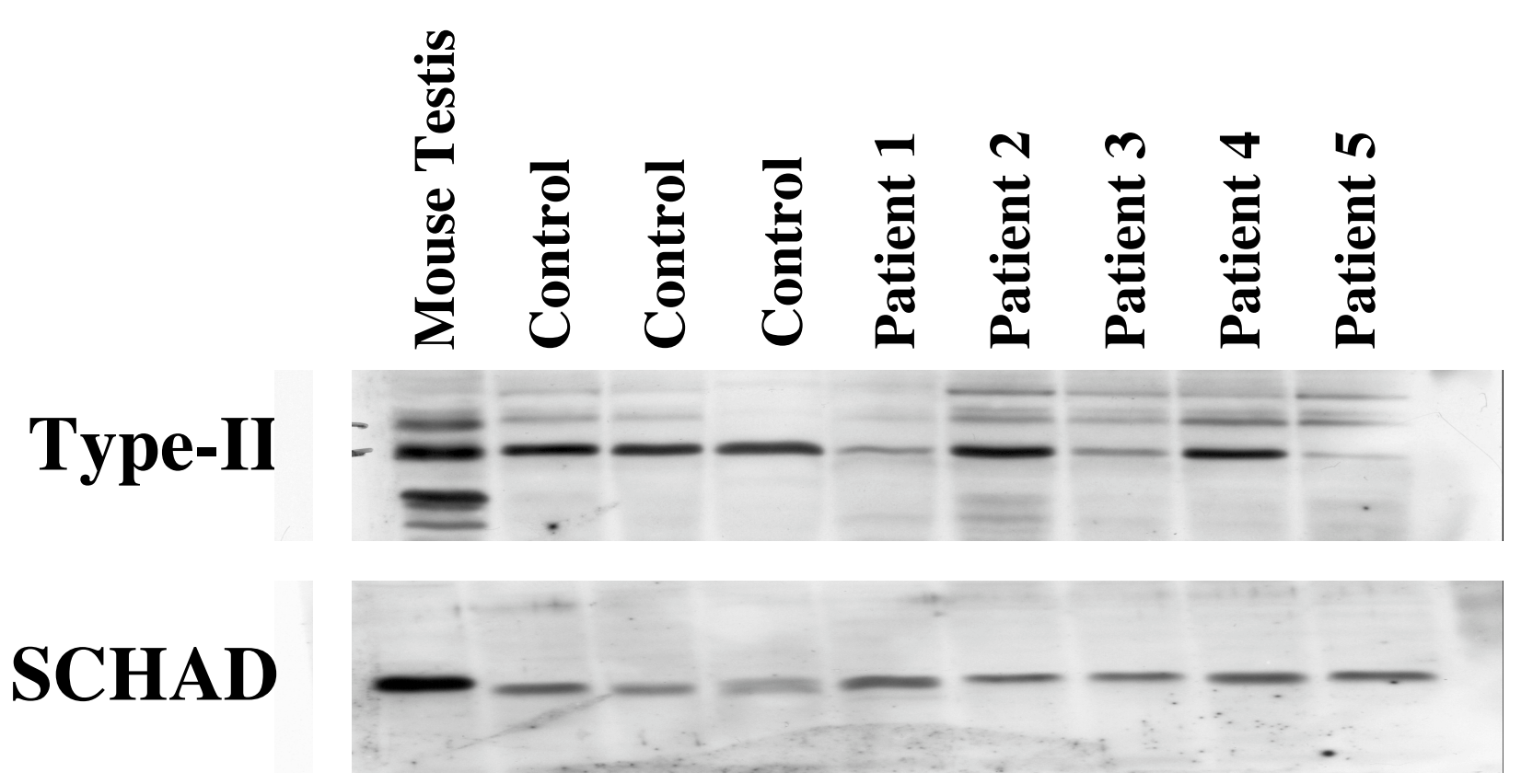


Fig. 4

B

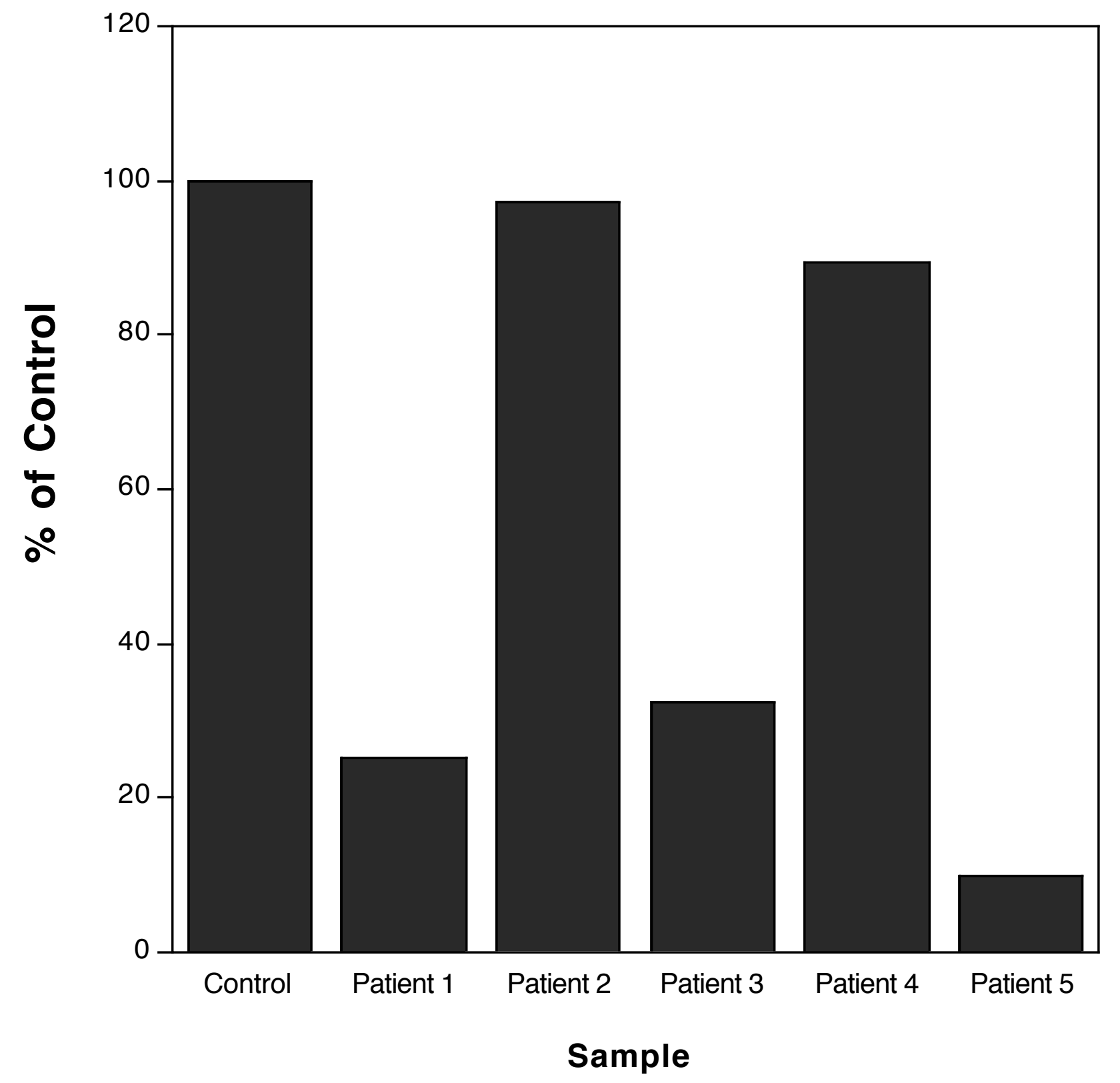


Fig. 5

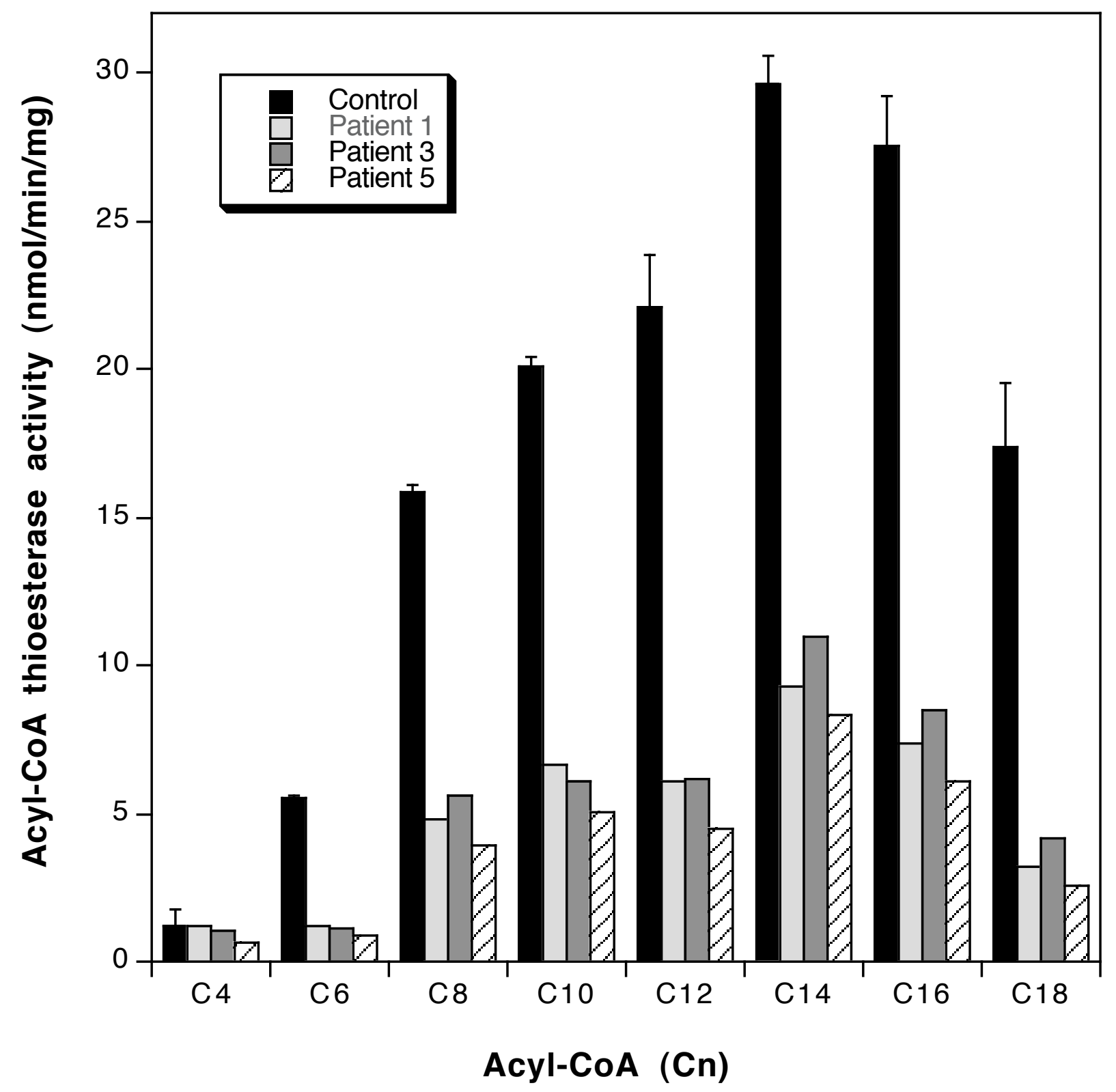


Fig. 6

A

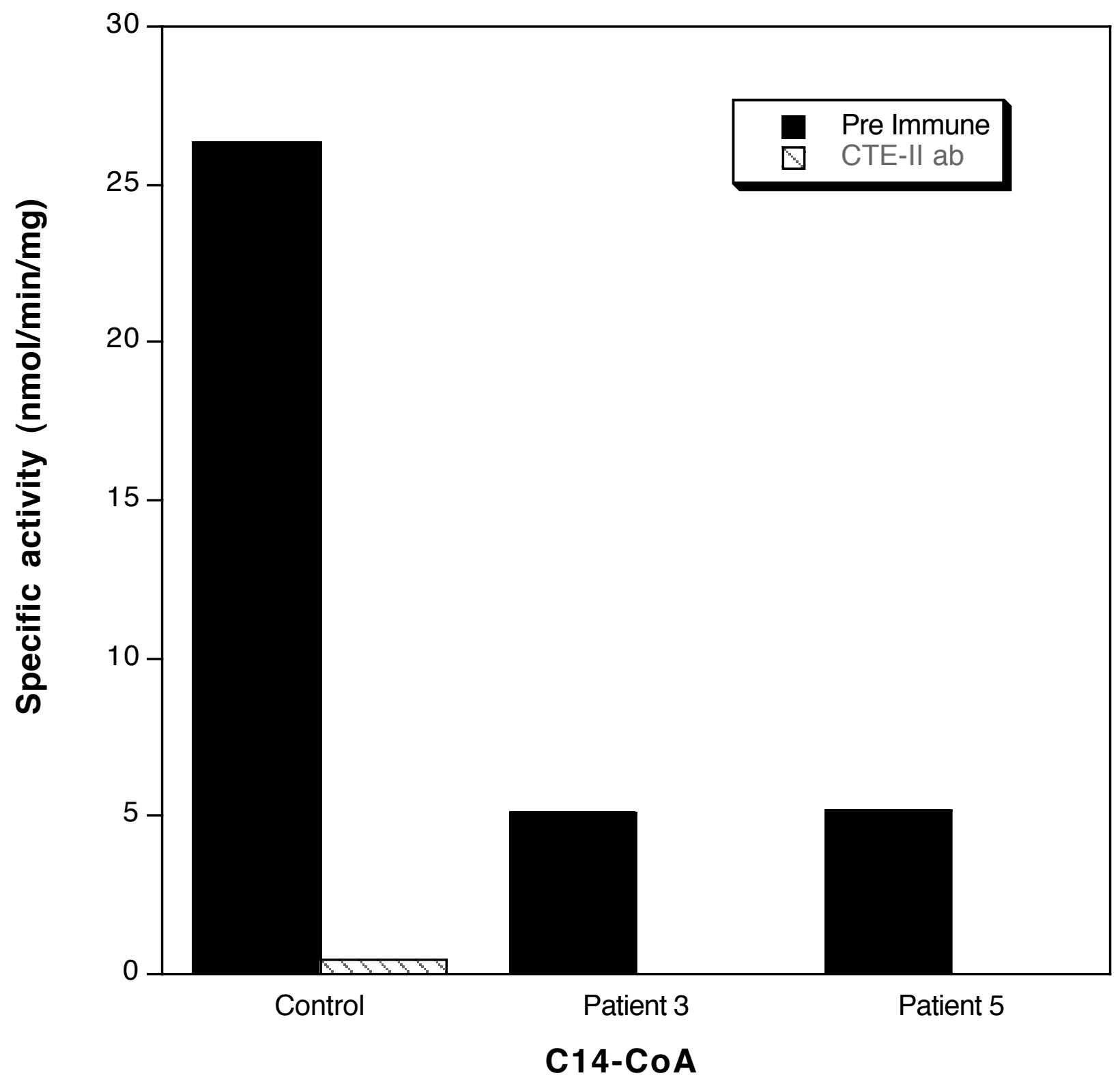


Fig. 6

B

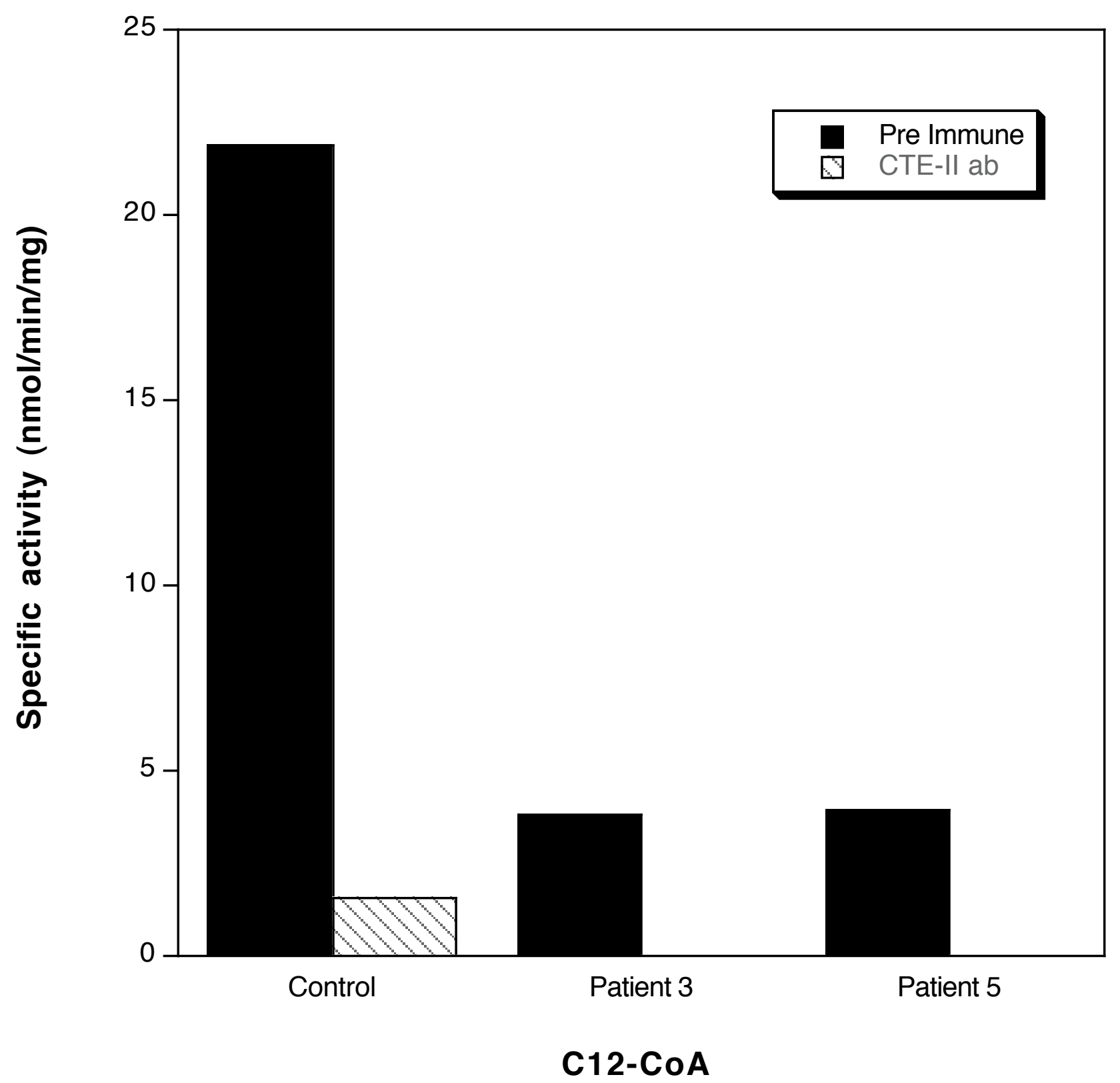


Fig. 6

C

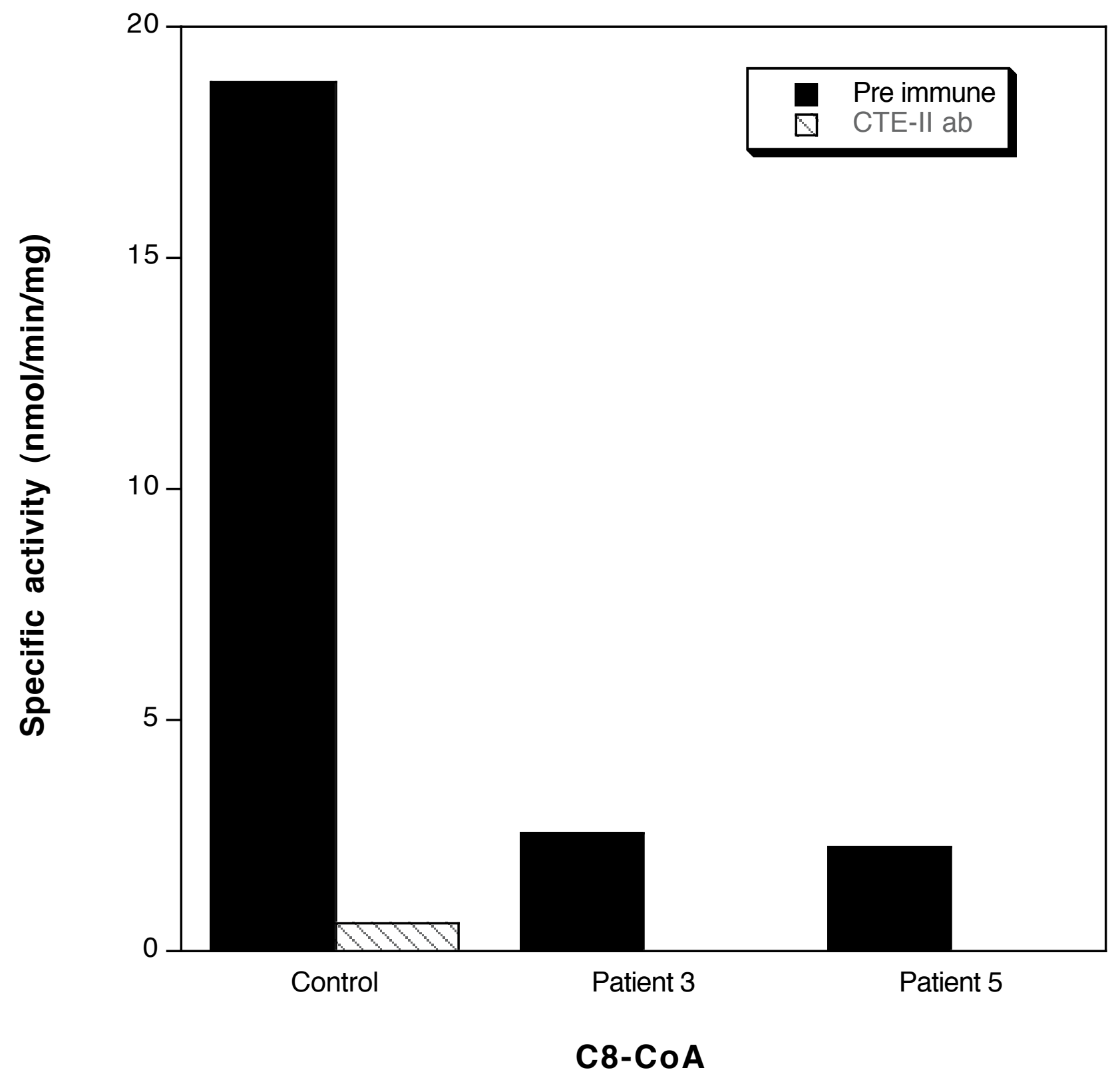


Fig. 7

A
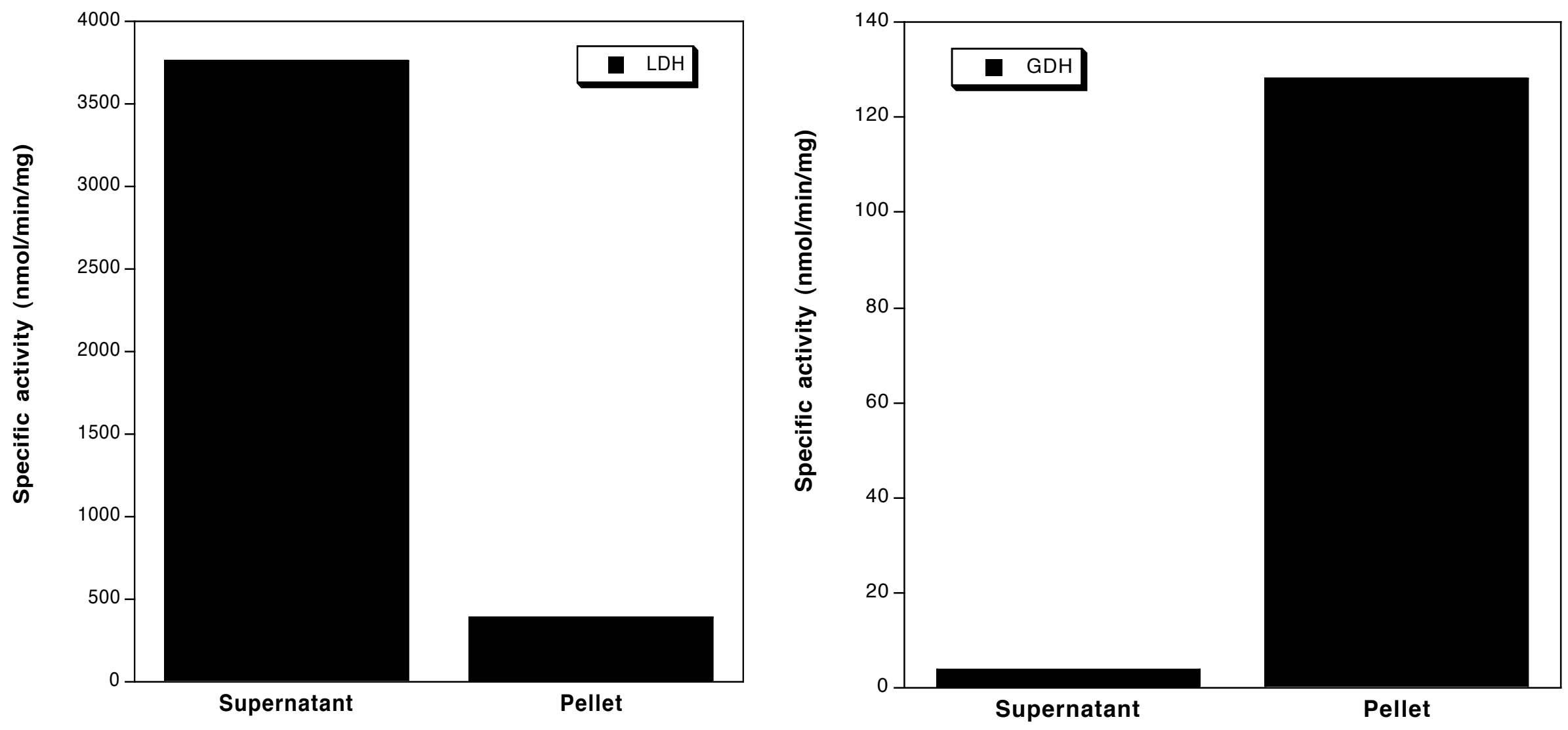
Fig. 7

B

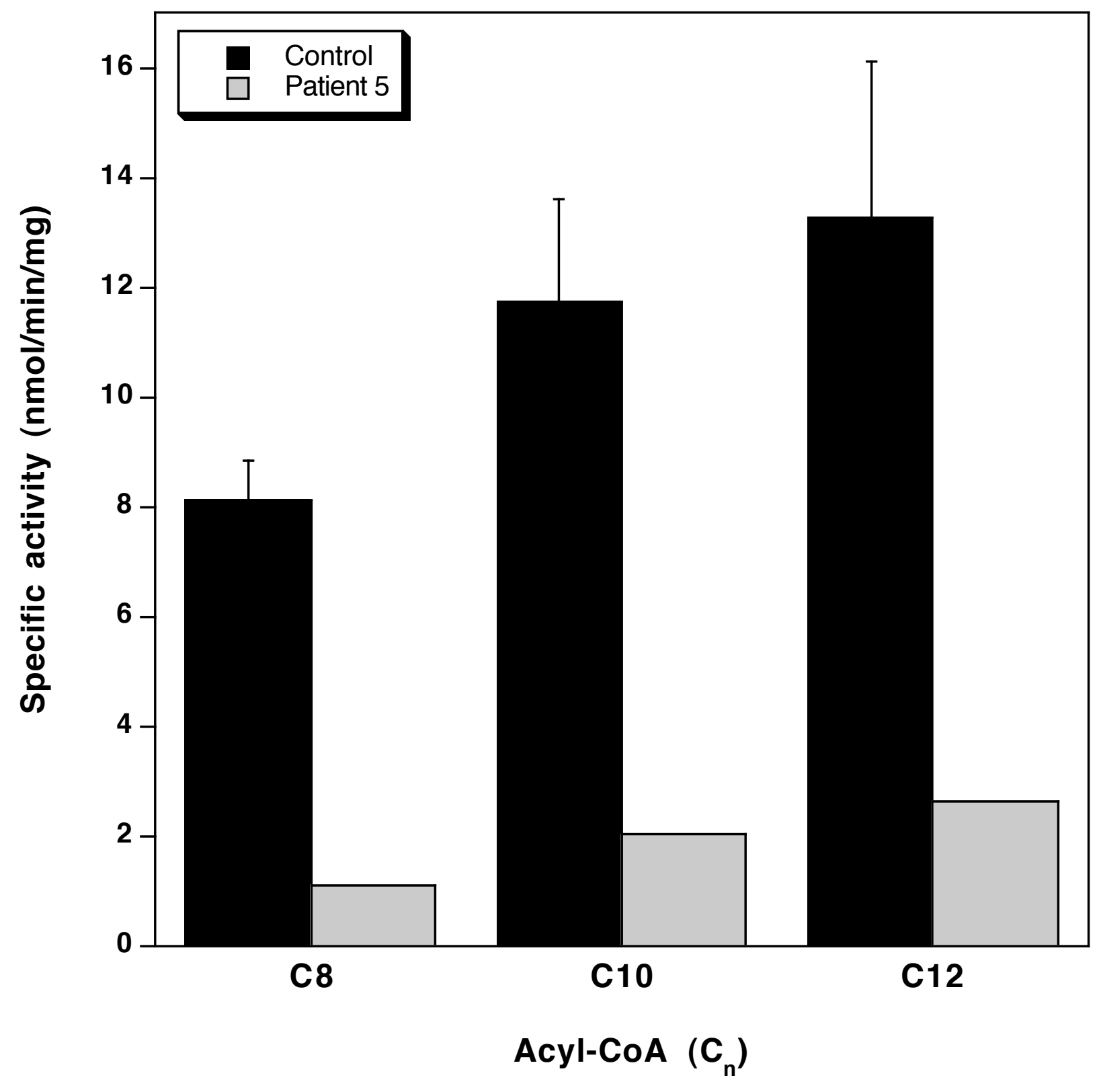


Fig. 7

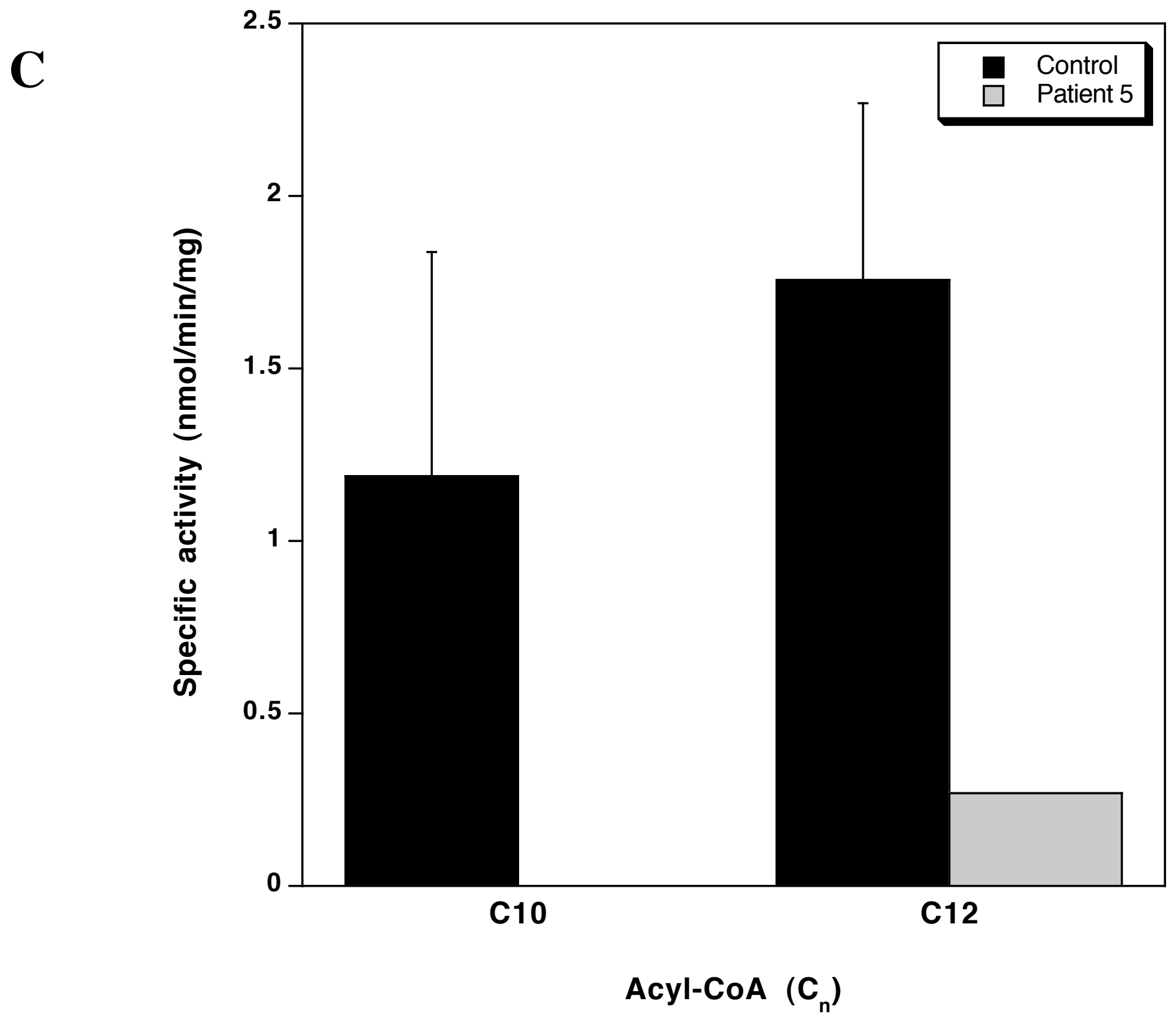

